\title{
MUSIC IN WESTERN RENAISSANCE AND MODERN CULTURE
}

\author{
Paolo Gozza \\ Universitá di Bologna - paolo.gozza@unibo.it
}

\begin{abstract}
This article focuses the contribution of music to the construction of the scientific image of the world and of man in the European culture. It is divided into three main sections: the first one discusses the ancient and Renaissance concept of Harmony. Renaissance Harmony includes Number and Proportion. In the second section, whose title is Sound, the Renaissance harmonious ideal is faced and somewhat disarranged by the modern scientific paradigm. The argument of the last section, Affection, is centred on the metaphor of man as a musical instrument. In my short conclusion I shall finally discuss the birth of the Eighteenth-century aesthetic paradigm of music as an art centred on man's pleasure, that took the place of the earlier classical and modern tradition centred on music as a science, which is the subject of my paper.
\end{abstract}

KEYWORDS: Poetics; number; sound; affection

RESUMO: Este artigo focalize a contribuição da música para a construção da imagem científica do mundo e do homem na cultura europeia. Divide-se em três seções principais: a primeira discute o conceito de Harmonia na Antiguidade e na Renascença. A Harmonia renascentista inclui Numero e proporção. Na segunda seção, cujo título é Som, o ideal harmônico renascentista é exposto e de certa forma desorganizado pelo paradigma científico moderno. $\mathrm{O}$ assunto da última seção, Afeto, é centrado na metáfora do homem como instrumento musical. Na conclusão sucinta, discutirei o nascimento do paradigma estético da música no século SVIII, como arte visando o prazer, que tomou o lugar da tradição anterior, clássica e moderna, centrada na música como ciência. 
PALAVRAS-CHAVE: Poética; número; som; afeto.

1. Introduction: A Meeting in Musicology Music in WeSTERn TRADITION

My aim is to present to you a historical picture of the place that musical learning deserves within the European cultural tradition. While I was preparing my lecture, I realized that I had to deliver a speech that might be appealing first and foremost to the Brazilian graduates who are now listening to my words, as well as to their many teachers who have so kindly invited me to open the works of this edition of Poetica Musical in the modern age. Therefore, I focused my reflection, as well as hopefully my audience's attention, on a wide, overarching argument: the contribution of music to the construction of the scientific image of the world and of man in the European culture.

My account ambitiously covers about three centuries of Western musical culture, from the Renaissance to the Eighteenth century. It is fatally going to result both defective and oversimplified.

With regards to its lacks, I am confident that what is missing from my speech will be completed by the other colleagues' contributions that we shall listen to during these following days. And regarding oversimplification, I believe that sometimes we should be able to simplify if our aim is to sketch, as in my case, an historical overview spanning over more than three centuries.

I have divided my conference into three main sections: the first one discusses the ancient and Renaissance concept of Harmony. Renaissance Harmony includes Number and Proportion. It entails the shaping of an ordered, musical world as the common abode of mankind. We shall become aware of these musical concepts and of their widespread diffusion in Renaissance culture by looking at, and commenting on, some images and texts by renowned Renaissance sources.

In my second section, whose title is Sound, the Renaissance harmonious ideal is faced and somewhat disarranged by the modern scientific paradigm. The Moderns started the study of the nature of sound and scrutinized the acoustical laws that govern sounding bodies and musical instruments. The mechanical science and technology of sound, both natural and artificial, fostered in and expanded the scientific image 
of nature that modern culture was shaping, and revealed fresh boundaries to the theory and practice of music.

The argument of my last section, Affection, is centred on the metaphor of man as a musical instrument. The matter for the construction of this living miracle is the air, namely, the all-permeating vital element that fills up both the outside and inside of beings, including man. In man air is a living breath or pneuma, inhabited by the animal spirits that were believed to be responsible for the internal motions of the soul, called affections. Moreover, modern scholars considered air, or pneuma, as the building material of the human voice, either spoken and sung, and considered the voice as the sounding image of man's inner affections. Thus voice and affections are two complementary sides of the same living being.

In my short conclusion I shall finally discuss the birth of the Eighteenth-century aesthetic paradigm of music as an art centred on man's pleasure, that took the place of the earlier classical and modern tradition centred on music as a science, which is the subject of my paper.

Before embarking on this musical trip, I would like to discuss briefly my musicological perspective and the ways it may fit within this meeting.

My belief is that what primarily brings us here together is the interest in man. This interest extends far beyond our different intellectual traditions: it is our own globalization / internationalization, the one that does concern us more. The interest in mankind is the foundation of the universal intellectual ideal that has been rightly called The Republic of Letters, the greatest intellectual achievement that is always to be revived when and where our concern is culture.

However, in my opinion man has disappeared from learning. We study because it pleases us, because we are actually able to do it, and because the institutions we serve do pay us for doing so. All this is good and right, but a doubt arises whether all these different jobs have become ends in themselves instead of being the means to the study of man, who should stand at the core of all our projects.

One of the reasons of the disappearance of man from culture is the removal of historical learning. The siege of the Present annihilates historical knowledge, and we are no lon- 
ger able to make use of the past that preserves the images of man in their historical development. Our philosophies and aesthetics of music show confidence with such concepts as beauty, affection, mind, memory, listening, silence, language, imitation or expression, and so on. However, the impression one gets is that these are mostly empty words, lacking their historical meaning and content throughout the centuries. Moreover, anthropology of music and ethnomusicology, the other facet of musical studies, are often opposed to historical knowledge just as the study of the Present is opposed to the study the Past.-

We encounter man when we experience of physical or mental illness; in hospitals or in the consulting room of the psychoanalyst; in sickness or death (and this might explain why these two experiences tend to be removed from our existences.) We should try to recover man in our own musicological studies.

I think that this meeting in musicology might achieve a meaningful result if we shall be convinced that music is not an end in itself but only a means among many others for the study of man, who is the alfa and omega of learning.

Which are the key-concepts that summarize the nature of musical learning in the Renaissance and the Modern age? My answer is: Number, Sound \& Affection.

Number refers to the idea of Harmony as discordia concors, that is, the power of the mind, both Divine and human, to conflate and set things in tune, just as it happens in music, that wonderfully harmonizes different sounds and voices.

Sound refers to the scientific study of those ordered motions of the air that impress hearing and stir up affections. It refers also to the acoustic implementations of sound in engines or automata, by means of which the Moderns were able to modify their sonic environment.

Affection refers to the inner being of man and to his internal motions. It refers to the anthropological construction of man that has been achieved by modern musical learning through the competition of different sciences, above all medicine, acoustics and moral philosophy.

Both Number \& Affection have their ancient archetypes in the two mythological characters of Pythagoras and Orpheus. These two ancient figures were revived during the Renaissan- 
ce and throughout Modernity. Pythagoras was revived in the myth of universal harmony that unifies opposition and creates a cosmos; Orpheus revives in the myth of "the wonderful effects of ancient music", which was brought to life in the age of the European musical Humanism by modern music.

Number, Sound \& Affection are music's contribute to the making of the scientific image of the world and man in Western culture. Music had a unique place and history in the European cultural tradition. Its history is very distant from the history of the visual, performing and media arts, with which music shares today the university-curricula and the public scenes. In the great cultural taxonomies of Western learning, from the Greeks to the Eighteenth century, music had been conceived as a science firmly settled into the mathematical and natural sciences, from the medieval quadrivium to D'Alembert's and Diderot's Dictionnaire. Only from the second half of the Eighteenth- and throughout the Nineteenth-century has music as a science lost its paramount position in the encyclopaedia of learning to the advantage of the modern concept of music as an art linked to the sister, elegant arts of painting sculpture theatre and dance, with which music has been sharing the European artistic imagery since the age of Romanticism.

This radical change in the concept and meaning of music has supported the loss of interest in earlier traditions of musical culture that have gone astray from our musicological values. It is revealing that the extant revitalization of musicology is encouraged and carried on by those disciplines that the Western musical canon has in fact marginalized: musical anthropology and ethnomusicology, the studies of ancient Greek's musical learning, medieval music, musical iconography, and the science and philosophy of music in its historical context. These researches, and the present meeting among them, are an attempt to renew the mentality and methods of musicological studies, in so far as they risk to distance themselves from the humanities or to lose their intellectual meaning and purpose while / by attending the stages.

\section{NUMBER}

Let us now have an insight into the constellation of concepts that are historically connected to the idea of Number. 
First Harmony; the ideal compendium of the Renaissance and Modern meaning of music.

When we speak of Harmony in Renaissance culture, we have to bear in mind that, at the beginning, before becoming a modern musical concept and structure, Harmony was the name of a woman. In Greek mythology, Harmony is the daughter of Ares, the Greek god of War, and Aphrodite, the Greek goddess of Love. Owing to this unique birth and origin, Harmony has got the general meaning of the tuning of two opposing qualities as quarrel and love, destructive impulse and affective holding. In other words, harmony is not the lack of suffering, but the power that restrains, includes and takes up suffering and the dissonances of life into a harmonious whole.

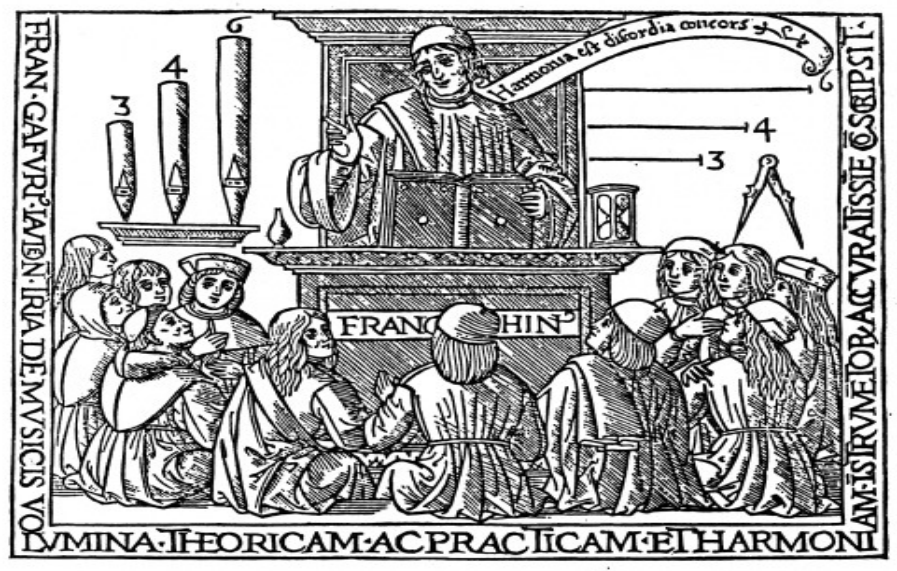

Lezione di Francbino Gaffirio

Xilografia dall'esemplare dell'Angelicum ac divinum opus musise di Franchino Gaffurio (Per Gotardum de

Ponte, Milano 1508) conservato presso il Civico Museo Bibliografico Musicale di Bologna

Fig. 1: Xilography from Angelicum ad divinum opus musice by Franchino Gaffurio (Gotardum de Ponte, Milano). Civico Museo Bibliografico Musicale di Bologna

In Renaissance writings on music, the evidence for such a concept of Harmony is shown already in the title page of a treatise written by one of the most important music theorists of musical humanism, namely Franchino Gaffurio (14511522) (fig. 1). Harmonia est discordia concors, harmony is a discordant, conflicting concord, Gaffurio confidently says to his audience. The inscription stands at the front of the house of music, and is the universal musical law that applies to all beings. The engraving also shows the image of the renaissance 
musicus as it was portrayed by Boethius (480-526) in chapter 33 of his De musica.

Harmonia as discordia concors is the answer to a major cosmological question: why does not the world collapse?

Which is the secret, invisible power that conflates and unites the opposing parts of the universe and of man?

The answer is, as in Gaffurio's sample, Harmony as Number and Proportion. Number and Proportion are the mathematical, formal bonds that link different or opposing realities in order to shape a coherent, consistent living World. In this picture you note the paramount presence of number and measure as mathematical concepts that elucidate the meaningful inscription whispered by the music teacher.

For Renaissance culture and for the modern scientific mentality, up until Isaac Newton and Leibniz or Immanuel Kant, Harmony as Number and Proportion is the secret musical law of Being and of the mind that contemplates it. When we speak of music in the Renaissance and modern culture, we should try to put aside the current concept of music. During the Renaissance and the modern age, music is a heterogeneous, hybrid science: it does not know the Romantic aesthetic principle of Art-autonomy, and is by no means self-referential. In the Renaissance and modern culture, music is the result of different sciences and practices, that together compete and converge in order to define the nature of music, its forms, aims and its changing place in the universe of knowledge.

We find an extraordinary testimony of the concept of Harmony as discordia concors and of its mathematical structure in the writings of the greatest music theorist of the Italian Renaissance, Gioseffo Zarlino (1517-1590). In the fifth chapter of the Isitutioni Harmoniche (Fundamentals of Music) Zarlino writes:

I say that music in general ... is no other than Harmony; and we can say that music is that quarrel and friendship Empedocles posited, from which he thought everything had perforce to be generated; or, still in other words, that discordant concord (concertare), or the concord of various things that can be set to tune. ${ }^{1}$ (2011 [1558], p. 35).

Music is harmony in so far as music is that gentle force that restrains opposition and overtakes the negative. In still another chapter of his Isitutioni Harmoniche, Zarlino states that: 
1. In universale parlando, dico che musica ... non è altro che armonia; e potemo dire ch'ella sia quella lite e amicizia che poneva Empedocle, della quale voleva che si generassero tutte le cose, cioè una discordante concordia, come sarebe dire, concordia de varie cose le quali si possono congiungere insieme.

2. tutte le cose create da Dio furono da lui col numero ordinate; anzi esso numero fu il principale esemplare nella mente di esso Fattore. Onde è necessario che tutte le cose, le quali sono separamene over insieme, siano dal numero comprese e al numero sottoposte, imperocché tanto egli è necessario, che se fusse levato via, prima si distruggerebbe il tutto $[\ldots]$..» all created things were ordered by God in number; Number was indeed the first Archetype in the Mind of God the Creator. Thus it is necessary that all things that are either divided or united are grasped with, and submitted to, number, since number is so essential that, be it removed, and the Whole would collapse. ${ }^{2}$ (Id. Ibid., p. 58).

For Zarlino and for the Renaissance culture, number, harmony and proportion are the mathematical means that God the Geometer and Musician has placed into the world in order to maintain and preserve the Being from dissolution.
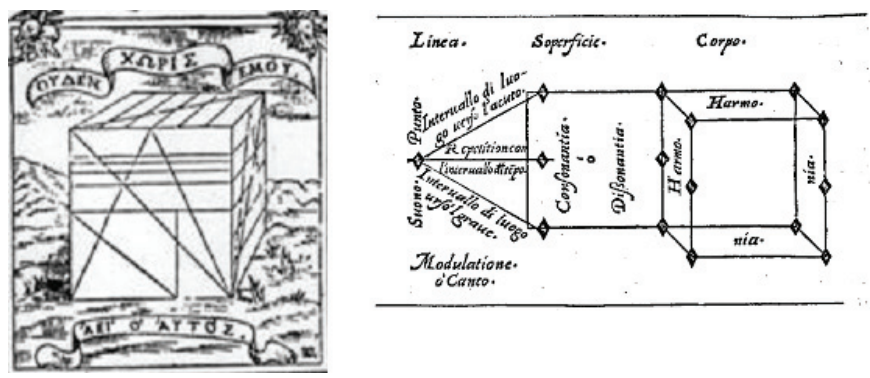

Figs. 2-3: G.M. Artusi. Impresa di Zarlino (Bologna, 1604)

The images above (figs. 2-3) show Zarlino's impresa or emblem, which illustrates the title page of the Impresa (Bologna 1604) written by Zarlino's advocate Giovanni Maria Artusi (1540-1613). The emblem shows a square-cube, one of the regular polyhedron rediscovered by Renaissance mathematicians (see De divina proportione by Luca Pacioli). It has the inscriptions: Nothing without me and Always the same. The square-cube is the emblem of the musical harmony of the world since all things would collapse without it, and never be the same. Harmony is the cosmological law of Unity and Variety that governs on the Whole.

It is of the greatest historical interest that the constellation of concepts stemming from and around Harmony, is not only to be found in the major Renaissance treatises on music. Most significantly, harmony, number and proportion are the pivotal concepts in different renaissance and modern disciplines, from metaphysics to cosmology, from astronomy to geometry, not to say magic and the so-called occult sciences.

For example, in the writings of Niccolò Cusano (1400/011464) Number stands as the principle that allows the mind to think of the Being: 
I say that the Model of all the notions in our mind is Number. Without Number the mind can do nothing ... Number in our mind is the image of the divine Number that exists in God's Mind. ${ }^{3}$ (CUSANO, 1972 [1450], p. 485).

Cusano also reminds us that "mind is derived from measure.» (Mens derives from metior-iri, which means 'to measure'). Since it is the true image of the Divine Mind, human mind numbers and orders things, therefore the number in our mind is the image of the Number that exists in God's mind:

Moreover, if I observe more precisely, I see that the unity that is done by number is like the octave, the fifth and the fourth in our music. The music interval is the unity that cannot be grasped without number. ${ }^{4}$ (Id. ibid. p. 483).

In other words, the number demonstrates its power of conjunction and cohesion primarily in music as the harmony of different and contemporary voices, discordia concors.

The universal meaning of harmony and music had been stated some centuries earlier in one of the most important and read treatises on music in Western culture, Boethius' De musica (480-526). The Renaissance inherited from Boethius the threefold structure of music, mundana humana instrumentalis (wordly, human and instrumental music), so extending music to all beings (Musica ad omnia se extendit, music applies to all beings, a medieval source proclaims): mundana refers to world music, i.e. to the order and proportion inherent in the world; humana is music inside man, the Greek eutimia, the good mind-body relationship; finally instrumentalis is the mathematical theory of living, extant music, made of by the concords of voices and musical instruments (fig. 4).

The universal idea of music that the Italian Renaissance inherited and passed down can explain why we find the study of music where we would not find it now, for instance in an astronomy book.

Johannes Kepler's (1571-1630) epitaph reads as follows: "Mensus eram coelos, nunc terrae metior umbras. Mens coelestis erat, corporis umbra iacet" [I had measured the heavens, now I measure the earth's shadows. The mind was heavenly; it rests like the body's shadow].
3. Parimenti dico che l'esemplare delle concezioni della nostra mente è il numero. Senza il numero essa non può far nulla ... Il numero della nostra mente, in quanto è immagine del numero divino che è l'esemplare delle cose, è l'esemplare delle nozioni.

4. Anzi, se guardo più acutamente, vedo che l'unità composta del numero è come l'ottava, la quinta e la quarta nelle unità armoniche. Il rapporto armonico è l'unità che non può essere compresa senza il numero. 


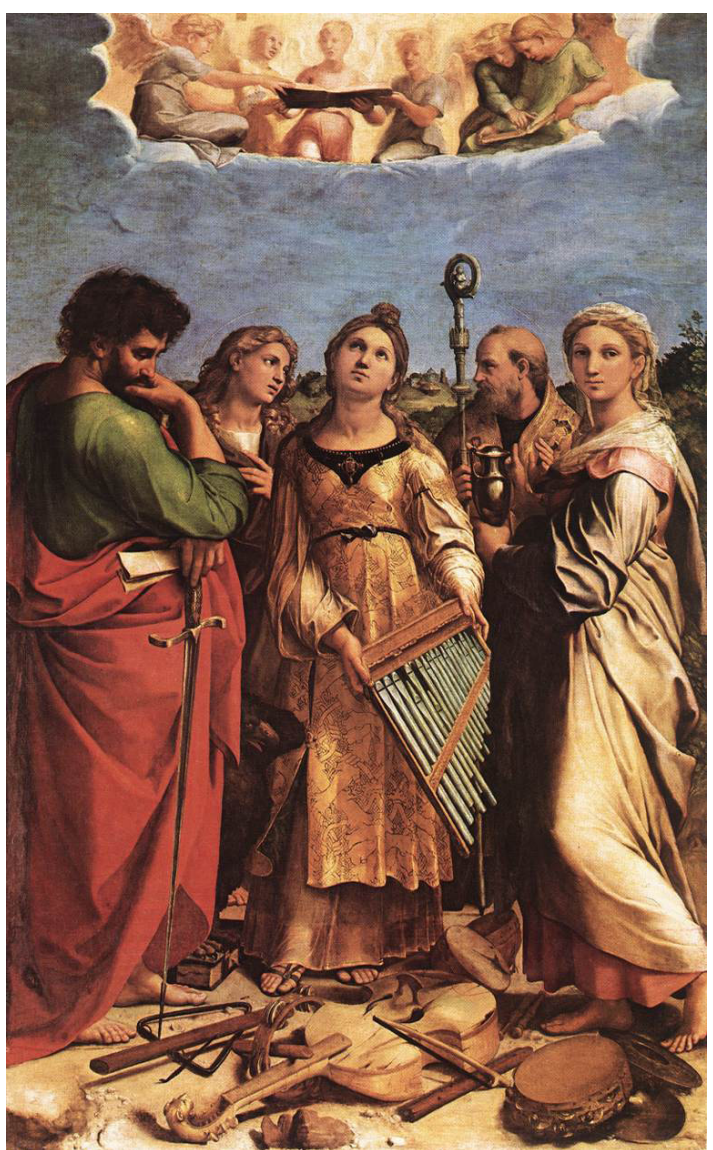

Fig. 4: Raphael: The Ecstasy of Saint Cecilia (1517). Pinacoteca Nazionale, Bologna, showing the 3 spheres of musica mundana, humana and instrumentalis

Of the five Harmonice mundi Books, the third on harmonies occupies the central place, between the two geometrical Books I and II, and the two astronomical books IV and V. Book III on harmonics is a musical treatise modelled on the structure of medieval and Renaissance treatises on music: to the theoretical part, musica speculativa, on the deductions of the consonances, Kepler adds a practical part, music activa, devoted to songs. Kepler placed music at the centre of the Book that God had waited six thousand years for. Modern music theory and practice stands as "the genuine archetype of cosmic work". In his attempt to reach the place where the secret harmony of the world has been hidden away for thousands of years, Kepler invites modern musicians to rise with 
him. It is through the ears of modern musicians that Nature manifested itself, just as it is, to the mind of man:

Follow me, modern musicians, and express your opinion on this matter by means of your arts, unknown to antiquity. Nature, always generous with her gifts, has at last, having carried you two thousand years in her wombs, brought you forth in these last two centuries, you, the first true likeness of the universe. By your symphonies of various voices, and whispering through your ears, she has revealed her very self, as she exists in her deepest recesses, to the Mind of man the most beloved daughter of God the Creature (...) The subject of music is sound, its purpose tug iv pleasure and arouse in us various affections. (KEPLER, 1940 [1519], v. 6, p. 323).

The incipit to the Compendium musicae (first draft 1618, first edition 1650) by Rene Descartes (1596-1650) sets music among the objects of hearing: sound, the object of musical theory, encounters the listener who draws pleasure and affection from the music. Pleasure is possible provided the sound has a mathematical structure purified by occult timbre qualities that cannot be quantified.

In view of the aim to give pleasure and arouse various passions, the means of music are two properties of sound: The ratios of duration or tempo, and of pitch in relation to acuteness and loudness. Let the natural philosophers study the quality of sound, i.e. from which body sound is produced and under which conditions it may be most pleasing. 5 (DESCARTES, 1987 [1650], p. 55).

Missing in the Compendium musicae of Descartes is one fundamental aspect of sound: the quality of sound, sound as a natural reality, subject of the natural philosophy, remains outside the mathematician's view, interested as he is in the quantifiable aspects of sound. And missing from the Compendium musicae is also affection, since Descartes himself says that a close inquiry of the music-affections relationship depends on a good understanding of the motions of the soul, de quibus nibil plura, on which no more, Descartes remarks.

Briefly: in Descartes' Compendium musicae there is number not sound, and pleasure sidelines the affections of the soul. In my view, Descartes' work marks the historical passage
5. Huius (sc. Musicae) obiectum est sonus. Finis, ut delectet, variosque in nobis moveat affectus. 
between a musical theory totally inscribed in the mathematical Pythagorean tradition that was improved by Zarlino, and the modern science of music based on the experimental study of those conditions that Descartes had banished, namely sound and affecction.

\section{Sound}

The title of my second section is Sound. Its historical context covers the age of the Scientific Revolution, as historians of science call the period between the publication of On the Revolutions of celestial bodies (1543) by Copernicus and Newton's Philosophiae naturalis Principia mathematica (The mathematical principles of natural philosophy, 1687), towards the end of the Seventeenth-century. The period is also known among historians of the European culture as the Baroque age, or again the âge classique, who's artistic and cultural values show a discontinuity in relation to the Renaissance culture.

After the publication in the Eighties of Floris Cohen's seminal book, Quantifying Music, that followed earlier researches in musical science by Daniel P. Walker, much has been done during these thirty years in order to assess the science of music during the Seventeenth and early Eighteenth centuries. I shall not discuss now these achievements. I prefer to call your attention to some historical aspects that could offer you a vivid idea, at least in my view, of the cultural novelties in the field of musical science and philosophy during that period.

In the field of musical learning, the novelty of Seventeenth-century science can be better portrayed in terms of the scientific study of sound, of its nature and its mechanical laws and properties. Baroque intellectuals tried to match the ancient and renaissance tradition of music grounded on number and proportion with a great amount of acoustical experiments based on designed observations on sounding bodies and musical instruments. Musical science was going to become a chapter within the mechanics of elastic bodies, and this changed the identity and content of music and its standing in the encyclopaedia of learning: the ancient and renaissance mathematical science of music, rooted in arithmetic and geometry, was now better and more precisely defined as a physic-mathematical 
discipline, like its sister-science of optics, astronomy and mechanics.

Just at the beginning of the Seventeenth century, the restoration of the study of sound found a great supporter in Francis Bacon's (1561-1626) writings. In his Sylva sylvarum (1627) Bacon declared that until that moment the nature of sound had been studied (II, 390) on the basis of a mathematical model that was confined «into certain mystical subtleties, of no use and not much truth» (id. Ibid., 385) The tyranny of the mathematical model in music has entailed that, Bacon continues, «the nature of sounds in general hath been superficially observed. It is one of the subtlest pieces of nature». For its subtle nature, sound had remained in Bacon's opinion, an occult side of nature that needed to be studied in its own properties. Bacon's Sylva sylvarum was the attempt to set forth an impressive project of inquiries and experiments never since imagined on the nature and the physical properties of sound: a programme that may be fairly called the shift from number to sound.

Around the same period, Marin Mersenne (1588-1648) could announce the definitive move from number to sound. In his Harmonie universelle he argued that sound is no more what earlier theorists abstractly considered, that is «without matter»: the number does not produce sound. For the modern natural philosophers, like Bacon, Mersenne or Galileo, sound is now best defined by the periodic vibrations of the air by which hearing can be affected and moved.

The air was in Seventeenth-century science the natural theatre of the actions of those subtle, invisible movements that we call sounds and that impress so vividly man's sensation. Mersenne expressed the primacy of air for the science of sound in this naive sentence:

We do live in the air as fishes live in water, but with this difference: we cannot split off the air ... as fishes do, who jump out of water... while we, on the contrary, always have more than fifty thousand weights of air above our head, since air reaches the moon, and maybe the firmament. ${ }^{6}$ (MERSENNE, 1637, p. 9).

Mersenne also stated that sound was no other than a peculiar motion of the parts of air. This is, in my opinion, an important point that has not been closely watched by extant 
6. Novs viuons dans l'air comme les poissons dans l'eau, mais auec cette difference que nous ne pouuons sortir hors de l'air, ny arriuer à sa surface, comme il font, car ils sautent souuent hors de l'eau, ou se tiennent dessus, mais nous auons tousiours plus de cinquante milles lieuës d'air sur la teste, car il s'estend iusques à Lune, $\&$ peut-estre iusques au Firmement. historiography. In early modern science, air and sound were joined together and their proper, individual nature was still uncertain. Only slowly and throughout many conceptual difficulties did sound distinguish itself from its sympathetic conflation with air. Moreover, air is not only an agent in the external world, intertwined as it is within the spaces that surround us from everywhere; air is also an internal element, it is found inside living beings, as men and even small insects. And, moreover, internal air partakes of the principle of life.

Robert Boyle (1627-1691), the British philosopher who more and better than anyone else in his age scrutinized the properties of air according to the scientific method of the Moderns, expressed the congruity of air and life in his New experiments... touching the spring of air (London 1660). Following the observation that insects inside the air-pump collapsed when air had been removed, while, on the contrary, they revived when air had been restored, Boyle commented:

This invited us thankfully to reflect upon the wise goodness the creator, who, by giving the air a spring, hath made it so very difficult, as men find it, to exclude a thing so necessary to animals; and it gave us also occasion to suspect, that if insects have no lungs, nor any part analogous there unto, the ambient air affects them, and relives them at the pores of their skin, it not being irrational to extend to these creatures, that sentence of Hippocrates, who saith, that a living body is thoroughout respirable; or ... disposed to admit and part what is spirituous.» (BOYLE, 1772, "Experiment XLI", p. 112).

The admirable story of the bird-catcher, recorded in Galileo Galilei's (1564-1642) Il Saggiatore ["The Assayer"] (1623), is an impressive testimony of the modern scientists' difficulty (or perhaps attitude) to think of air and sound as indivisible from what we call life. Galileo recounts the story of a man endowed by nature with an extraordinary curiosity. His pastime was to raise birds, whose songs he much enjoyed and he observed with great admiration the happy contrivance by which, as Galileo says, «they could transform at will the very air they breathed into a variety of sweet songs.» One day this man having captured in his hands a cicada, he failed to diminish its strident noise either by closing its mouth or stopping its wings: 
At last, he lifted up the armour of its chest and there he saw some thin hard ligaments beneath; thinking the sound might come from their vibration, he decided to break them in order to silence it. But nothing happened until his needle drove too deep, and transfixing the creature he took away its life with its voice, so that he was still unable to determine whether the song had originated in those ligaments. And by his experience, his knowledge was reduced to diffidence, so that when he was asked how sounds were created he used to answer tolerantly that although he knew a few ways, he was sure that many more existed which were not only unknown but unimaginable. (GALILEI, 1979 [1623], p. 126-128).

Air, breath, song and voice coalesce and merge, at the same time concealing the origin of life from man. The mistrust in human knowledge declared by Galileo's bird-catcher arises from the presumption of the human mind to finding out the cause of sound and, being sound intimately related to air and breath, this would mean finding out the secret of life.

In the modern studies on sound, one of the most observed natural event was the phenomenon of echo. Echo was a fascinating subject to the natural philosophers willing to discover the mathematical laws of sound and their applications to acoustical technology. Why was echo so extensively observed and studied during the Seventeenth century? One of the main reasons for such a widespread interest into the nature and properties of echo is that, among the sounding natural events, echo is a highly spectacular occurrence that inflames to a high degree the scientific imagination, a faculty of the mind that was highly appreciated by the Baroque scholars. Moreover, echo wanted to be observed and experimented in the open air, not only read or studied over books, as it is stated by the Jesuit mathematician Giuseppe Biancani (1566-1624) at the end of his Echometria (1620), one of the first treatises on echo in the modern science:

And these are the facts that last summer, when we ventured into the country for amusement and relaxation, not from others'
7. «...e finalmente, alzandole il casso del petto e vedendovi sotto alcune cartilagini dure ma sottili, e credendo che lo strepito derivasse dallo scuoter di quelle, si ridusse a romperle per farle chetare, e che tutto fu in vano, sin che, spingendo l'ago più a dentro, non le tolse, trafiggendole, colla voce la vita, sì che né anco poté accertarsi se il canto derivava da quelle: onde si ridusse a tanta diffidenza del suo sapere, che domandato come si generavano i suoni, generosamente rispondeva di sapere alcuni modi, ma che teneva per fermo potervene essere cento altri incogniti e inopinabili. 
8. Atque hæ sunt quæ superiori æstate, rura relaxationis causa incolentes, non ex aliorum libris, sed $a b$ experimentis, vobis de hoc vocis miraculo, vt ait Plato, geometricauimus.

9. Voila comme le Createur a donné vn langage aux bois, aux riuieres \& aux montagnes, pour le loüer $\&$ pour le benir en son admirable disposition, dont resulte l'harmonie rauissante, \& la belle symmetrie qui est admirée des vns, \& examinée \& mise en pratique par les autres, \& imitée en tous les chefs-d'œuures de l'artifice humain. books, but from experiments we were able to geometrize, as Plato says, about this miracle of the voice. ${ }^{8}$ (BIANCANI, 1620, p. 442).

For modern natural philosophers and mathematicians, echo is the miracle of voice, and its nature stirs up scientific imagination. Thus in the Treatise on echo that he includes in his Harmonie universelle, Mersenne writes that echo is the voice that, after Adam's language, God the Creator gave to Nature:

And this is how the Creator gave to the woods, rivers and mountains the language appropriate [i.e., the voice of echo] to praise and bless Him, for the happy harmony and the wonderful symmetry he posited in the world, and which is worshipped by some, studied and put into practice by others, and imitated in all the great creations of the human art. ${ }^{9}$ (MERSENNE, 1637, p. 56).

Moreover, philosophers and intellectuals wished to find out the beginnings of their own inquiries in ancient myths and wisdom. For example, they had learnt from Ovid and other renaissance sources that Pan, the god of peasants and the minor deities of the woods and pastoral landscape, the Great Pan whose name stands for the wholeness, had loved two nymphs who were intrinsically musical: they were Syrinx and Echo.

Syrinx escaped Pan's advances at the price of being transformed into the pipe played by Marsia and the peasants. The nymph Echo was even more loved even more by Pan for her voice that does repeat with fidelity what Nature, i.e. Pan, dictates. This is exactly Bacon's reading of the myth of Pan and Echo: in his De sapientia veterum Bacon says that Echo is Pan's husband and maintains that Echo is the image of the true philosophy because she truthfully repeats the decrees of Nature, i.e. of Pan.

At the end of the Seventies, in his Speaking Trumpet, the Italian astronomer Geminiano Montanari (1633-1687) impressively summarized the widespread discussion about echo by saying that "He who is not astonished by the Echo's marvellous nature, will not be astonished by anything else in the world.» (1678, p. 16). 
I hope that my effort to place you within the context of the modern epistemology of sound has turned out clear enough. I want now to examine the peculiar contribution to the science of sound given by Jesuit Seventeenth-century scholars. I shall mainly discuss Athanasius Kircher's (1602-1680) Phonurgia nova (The new atelier of sounds, 1673), that was meant by its Author to ruin the Tuba stentoro-phonica (High-echoing trumpet: 1671), written just two years before by a member of the Londonist Royal Society, Samuel Morland.

Morland's title recalls the myth of Stentore, the herald of the Greek army beneath the walls of Troy, whose voice was credited to equal the voice of fifty men together, and who later died because of his defeat in a vocal game against Hermes.

Which is the relationship between Stentore's story and Morland's megaphone, as we might also call his Tuba stentoro-phonica? What kind of scientific concern lies behind these different historical actors?

The answer is the commitment of the European scientific communities in the Sixties and Seventies to handle the powers of sound by means of newly discovered technological devises, such as Morland's tuba or megaphone, Kircher's acoustical engines, or Montanari's Speaking trumpet. The technological enforcement and strengthening of sound by way of new acoustical machines promised to increase man's sovereignty over the world.

We should remember that sound is an extraordinary natural event. Invisible and ungovernable, capable to rapidly cover wide extensions and ready to overcome different obstacles and to affect all beings and things in its high-speed passage in the regions of the world, sound inflames the imagination of Baroque intellectuals. The Baroque science of sound shapes and changes the forms of the world through the mastery of sounds: the echometria quantifies the environment, improves communication at distance, discovers acoustic spying; phonoscopia studies human temperaments through the voice, as physiognomia pictures man through his external, visual image; new architectural spaces and public buildings, as theatres, are constructed using sound as a power of shaping things. The Baroque acoustic imagery changed the Renaissance forms of the world: the objects curve and gain depth, their shapes are round, elliptic and parabolic, according to the geometry 
of conical sections. The modern study of sound defines the concept of soundscape and its anthropological pendant, the musical man (whom we will see later). In the Baroque scientific culture the soundscape is the encyclopaedia of learning. In it the literates do observe, record and quantify the many voices that the divine Designer has marked down in His musical work. Around the sonic environment scientific and philosophical traditions are renovated, acoustical instruments are projected for military as well as civil uses, a system of communication at distance is invented, different pathologies are treated, new acoustical and mathematical models are theorized.

In Kircher's Phonurgia nova (fig. 5), the ideology of Baroque absolutism is close to properly become the imperialism of sound over man and nature.

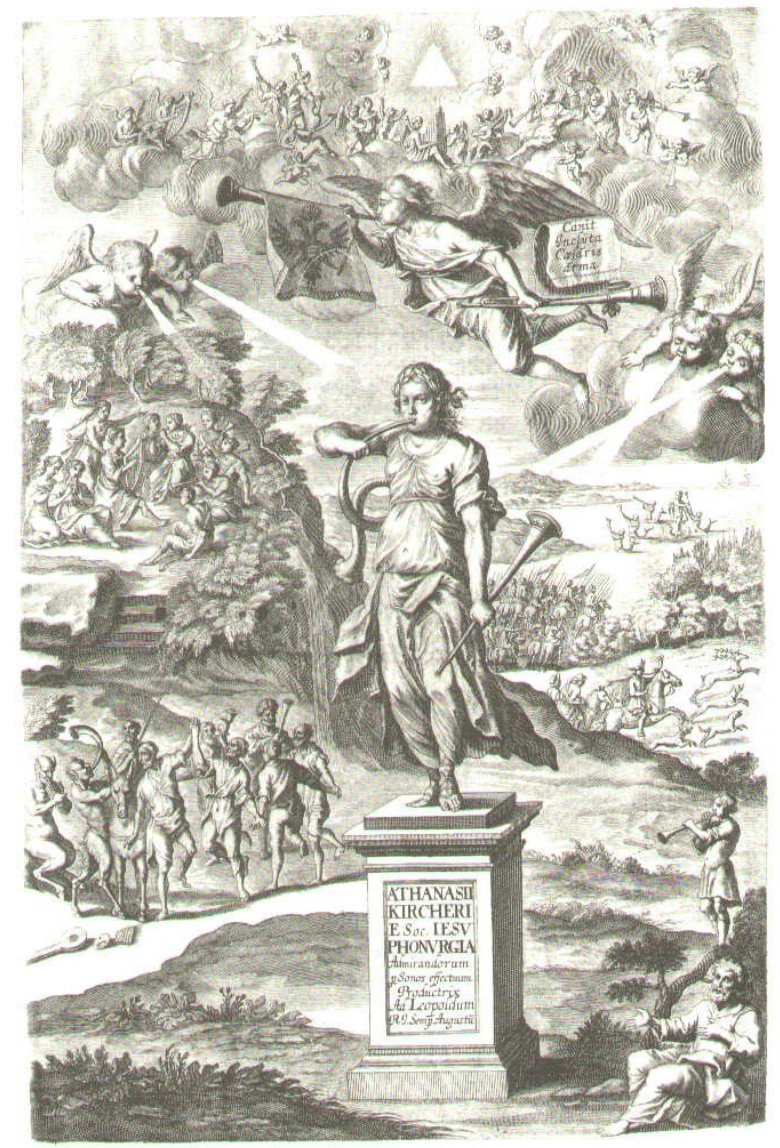

Fig. 5: Athanasius Kircher. Phonurgia Nova [The new atelier of sounds] (1673) 
As you can see from the image, the frontispiece of Kircher's Phonurgia reverberates sounds from right to left, from heaven to earth. These sonorities are produced by wind instruments: trumpets, horns, cornets, pipes, all invading the world with their pervasive cacophony. Sounds reflect and repeat, and give birth to a deafening wave of echoes that fill up the world and affect all its beings. Air is the medium of this sounding tempest that falls down from the sky to the earth and sea, beyond and over men's head.

Kircher's dedication of the book to the Austrian Emperor Leopold I is a declaration of muscular strength through the medium of sounds:

I shall rise up my voice with the powerful sound of the trumpet, I shall quake the heaven's roof with the polyphonies of the armies, I shall oppress the listeners' minds and ears with the martial roars of corns and pipes; I declare that I shall play the most Powerful trumpet that heralds the heroic virtues of the Roman Emperor Leopold I ... ${ }^{10}$ (KIRCHER, 1673, p. .i).

Kircher's Phonurgia nova begins from the theoretical chapters of the book, designed to offer a general theory of sound and to define the laws of its motion through the air (in comparison to light), and of reflections. These laws are the foundation of what might be called acoustical hydraulics: the wild energy of sound is subdued and tamed, sounds are forced inside conduits, channels, tubes and pipes, where multiple reflections strengthen their mechanical energy, so that sounds can be easily spread and scattered around, throughout the world (figs. 6-7). Fig. 6-7: Kircher's Phonurgia Nova

Kircher's concept and ideology of the science of sound has an interesting aesthetical aspect. The Jesuit father shares the Baroque aesthetics of wonder, surprise and admiration, and he tries to accomplish this aesthetical aim through the mastery of new acoustical technologies. Kircher's aesthetical programme is that of weakening reality by widening its boundaries: by handling the effects of sound on people's mind, the Jesuit phonograph attempt's is to confuse the boundaries between reality and appearance, technology and imagination (figs. 8 -11). 


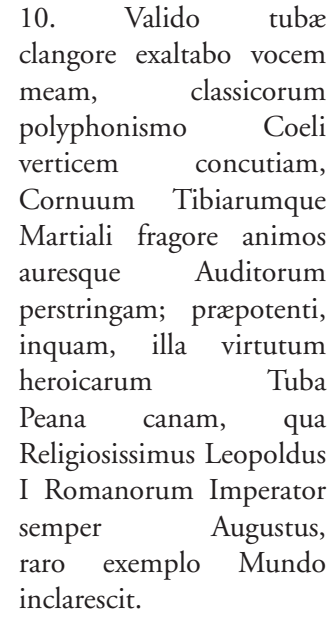

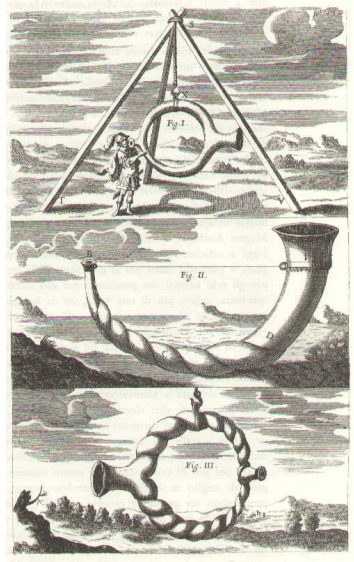

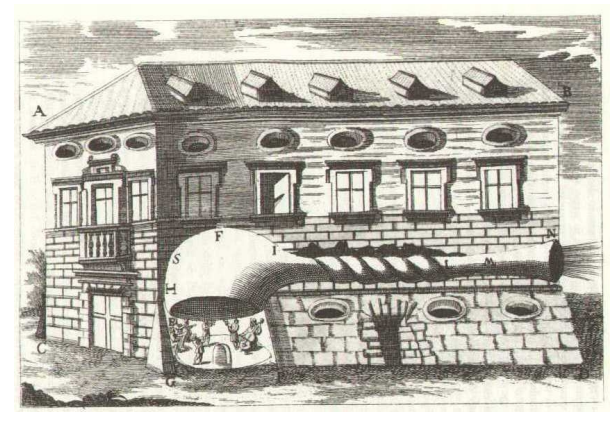

Figs. 8-11: Kircher's Phonurgia Nova

For example, one of the most impressive of his ideations is Kircher's acoustical instrument designed by his learned DJ with the title of Machina Harmonica Automata, musical automated machine. With the unique medium of air and wind, and without any need of cylinders or wheels, the musical automaton provides an enduring sound resulting most harmonious to the ears. The machine is made by a conic, rotating cylinder opened at the two circular bases. Inside the cylinder the fanciful sound-designer has placed a resonator made of 15 metal strings attached to a wood frame. The wind enters the cylinder and causes the strings to vibrate. People listen to its exotic melodies and are amazed and bewildered, since they cannot understand the occult cause of this extraordinary acoustical effect. This machine is the one that Johann Jacob Hofmann will later define in his Lexicon universale (Universal Lexicon: 1698) as "eolic instrument", acknowledging Kircher for its invention.

This instrument was an object of wonder and acoustical entertainment for people visiting the rooms of the Roman College where it was located. But it was also an instrument of scientific inquiry. Earlier in Musurgia universalis (1650) Kircher observes that the machine was able to produce complicated melodies and chords, and, most important, that one and the same string could produce different sounds simultaneously. In fact, the eolian harp is a resonating prism, and the executor of the acoustic diffraction is air: magic is exactly the occult art of impelling Nature to reveal the powers concealed in its womb, thus producing effects that divert people's minds from reality and confine man to appearance: 

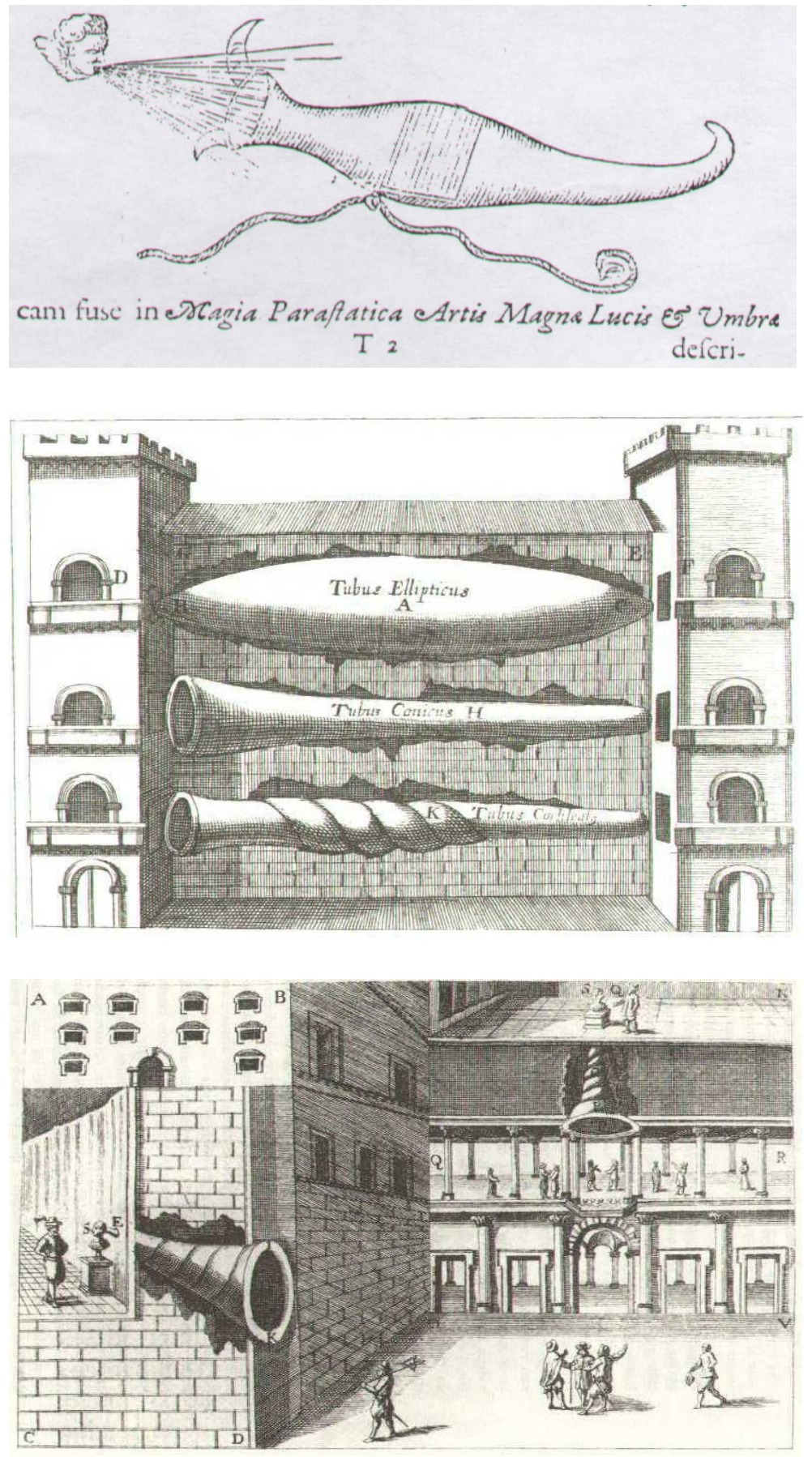


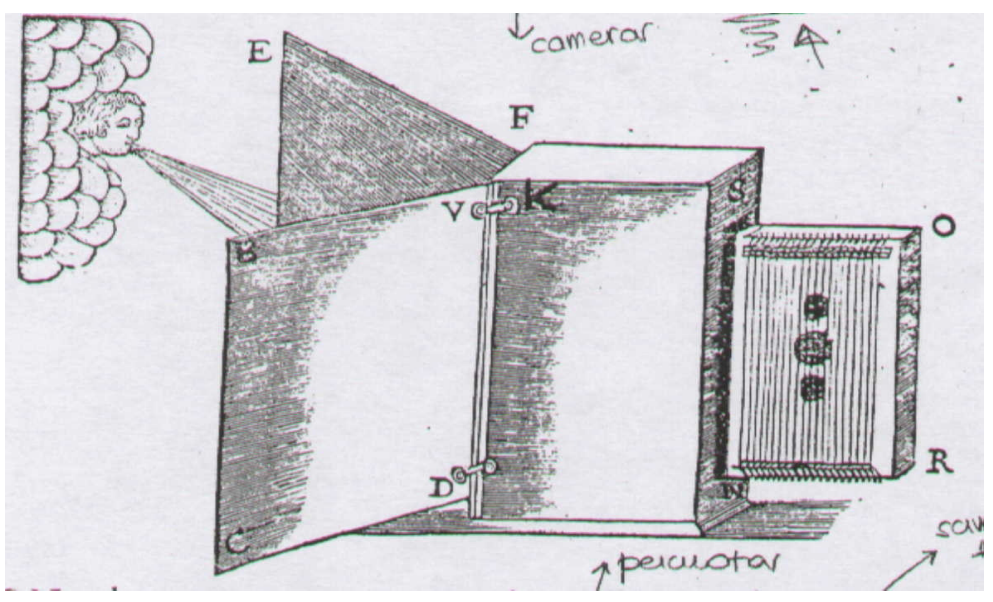

A shudder takes me...

The firm heart feels weakened and remote;

What I possess seems far away from me,

And what is gone becomes reality. ${ }^{11}$ (GOETHE, 1997 [1808],I, 27-32)

But in Kircher's own opinion, his most extraordinary achievement in the field of acoustical engineering was without any doubt his speaking statue. In Kircher's Museum this sounding miracle is visible and audible, and its name is Oraculus Delphicus. It is an oracular Head, able to speak and move the mouth and the eyes all around, without any other visible instrument. Being unable to understand the occult causes of the speaking oracular head, visitors suspect the occult presence of demons inside it. Quite the contrary, Kircher swears that the statue is produced by purely natural technology that combines different unknown arts:

Indeed, nobody can understand through which expertise the statue has been built, or which might be its occult moving cause, since the statue is hanging in the air, nor there are nearby channels and it is not activated by wheels, since it is the product of a purely natural craft that makes use of the combination of the most secret techniques. ${ }^{12}$ (KIRCHER, 1673, p. 190).

Kircher's speaking statue reminds us of the episode in Shakespeare's $A$ Winter's Tale (Act 5, Scene 3): the statue of the late Erminia, the Duke's husband, moves and comes 
down from its position. The deus ex machina of this miracle, Erminia's mother Paolina who arranged the affair, says to her audience that the miracle of the moving statue is not the result of an occult magical art: music alone gets the dead Erminia alive! Here we find once more the deep connections among life, sound, breath and air, all standing together as witnesses of life. Kircher's almighty Faustian technology was that of handling life through the subtle matter of spirit or pneuma, thus reminding us of Belzebu's words in Goethe's Faust.

\section{Mephistopheles:}

Reason and Science you despise,

Man's highest powers; now the lies

Of the deceiving spirit must bind you,

And I'll have you totally. ${ }^{13}$ (Id. Ibid., I, 1851-55).

\section{AfFECTION}

Kircher's speaking-head or Erminia's living-statue allow me to move on towards the third and last section of this speech, following number and sound, that is, affection. Affection is the anthropological achievement of modern musical learning. Granting ife to Kircher's statue would have meant creating an internal place or world as the living recipient of the affections. And this goal would have been achieved not by means of a Faustian trickery, but by the mutual concord of different scholarships. What was lacking from the German Jesuit's automaton was by no means sound or cry, but the word that recounts and represents in singing the passions of the soul, in the absence of which the statue would be an empty fortress, an autistic offspring.

The theory of the affections stands at the core of the construction of man carried on by modern musical learning. The extensive presence of this theme in modern culture is not only witnessed by the rhetorical tradition of musica poetica, from Burmeister and Kircher to Johann Mattheson. I think that if we want to grasp the facets of musical learning within its appropriate modern framework, we should have a look at other learned traditions which run parallel and beyond rhetoric and linguistics. These scholarships include the science of sound, anatomy and physiology, and the modern theory on the pas-
11. Es schwebet nun in unbestimmen Tönen | Mein lispelnd Lied, der Äolsharfe gleich, | Ein Schauer faßt mich ... | Was ich besitze, seh ich im Wetten, | Und was verschand, wir mir zu Wirlichkeiten.

12. Nemo tamen me
adunata polliceri sibi
persuadeat; quæcumque
promitto in effectum
infallibilem produci
possunt: Modum tamen (ne
tam sublimia arcanorum
mysteria ac solis Magnatibus
revelanda cuivis obvia
fierent) consultius silentio
supprimendum duxi.


13. Verachte nur Vernunft und Wissenschaft,/ Des Menschen allerhöchste Kraft,/Laß nur in Blend- und Zauberwerken/ Dich von dem Lügengeist bestärken/ So hab' ich dich schon unbedingt. sions of the soul: briefly, acoustics, medicine and moral. All these different cognitions contributed to the musical project of conceiving of man as the lively recipient of the affections, as well as providing him with the organs and operations that allow man to make his inner emotions visible and audible.

In order to think of the inner being of man, modern intellectuals looked at the musical instrument as a model: they established a scientific analogy between man and acoustic resonance, science of sound and anthropology. Thanks to the study of acoustic resonance, they had become aware of a fundamental requisite of musical instruments, namely their concave form and depth: the musical instrument is first of all a resonant body, and the study of the forms and geometrical laws of this body helped to conceptualize its acoustic properties. For example, the Italian natural philosopher Geminiano Montanari demonstrated resonance in the experimentum crucis that he describes in his La tromba parlante. The experimental observation consisted of a circular, concave vase full of water, inside which he threw small stones. The circular waves moved from the centre towards the border, then came back converging to the centre, endlessly repeating this to-and-fro motion. Montanari then extended this observation to musical instruments:

It is no wonder if in harpsichords, lutes, violas and other musical instruments the concavity of the body is necessary, in order to reinforce the original sound, since without this resonant concavity we would hear a very feeble sound. ${ }^{14}$ (MONTANARI, 1675, p. 1417).

This explanation of acoustic resonance was by no means a matter of a specific, acoustical science. Man too is a resonant recipient, able both to emit sounds through his body and voice, and to listen to the sounds and voices of the world that strike on his ears and alert and stir up his inner impressions. And memory, namely man's capacity to associate a here and now event to a past event, is anthropological, moral resonance, since, according to Diderot, memory functions like resonance because the fibres of our organs function like sensitive strings.

By imitating the model of musical resonance, man began to be conceived of by modern scholars through the analogy 
of the musical instrument, as we can read, to give an earlier example, in this passage of Zarlino's Sopplimenti musicali (Venice 1588):

The Organ obtained its universal and common name ... from a certain marvellous order and disposition of its natural parts: indeed it was constructed like a human body, since the pipes are equivalent to the throat, the bellows to the lung, the keys to the teeth, and who plays the instrument is the equivalent to the tongue; and the same is true for its remaining parts that correspond to the parts of man. ${ }^{14}(1588$, VIII, 3$)$.

About fifty years later Zarlino's Sopplimenti, in his unpublished Traité de l'homme, one of the outstanding work of modern medicine based on mechanical principles, René Descartes (1596-1650) found a deeper analogy between man and the musical instrument. Descartes set up a relationship between the organs of the churches and human physiology of the nervous system:

If you have ever had the curiosity to look closely at the organs in our churches, you know how their bellows push air into certain receptacles called, for this reason, wind trunks. You know also how from there the air enter the pipes, now one, now another, as the organist moves his fingers on the keyboard. (...)Now you can think of the heart and arteries of our machine (which push animal spirits into the cavities of its brain) as similar to the bellows (which push air into the wind trunks of organs); and you can also think of external objects (which, by displacing certain nerves, make spirits from the brain cavities enter certain pores) as similar to the organists' fingers (which, by pressing certain keys, make air from the wind trunks enter certain pipes). ${ }^{15}$ (DESCARTES, 1986 [1664], p. 114-115).

Descartes imagines man's nervous system as a pneumatic organ: instead of pipes and air, man has nerves and spirits, the latter being for Descartes «a kind of air or very subtle wind» that runs into the channels of the nerves. Just like the air inside the organ, the subtle airy spirits fill up the inner space of the human body, and their motions can explain many living functions as, for example, sensation and affection, that were once attributed to an immaterial soul and were now instantiated in man's bodily operations. On a cosmological plan, the
14. onde non è marauiglia se ne' Clavicembali, ne' Leuti, nelle Chitarre, Viole, \& altri musicali stromenti sia tanto necessaria la concavità d'un corpo, che presso alle corde rifletta quanto più vicina, tanto più sonora, e frequente l'Eco a riunirsi con la voce primaria delle corde medesime, perciò che senza di ciò non più oltre che un debolissimo suono di esse si udirebbe. 
15. l'Organo s'acquistò questo nome universale et comune d'Organo proprio et particolare, per una certa eccellenza delle parti naturali: percioche fu fabbricato alla guisa del Corpo humano, corrispondendo le Canne alla Gola, i Mantici al polmone, i Tasti à i Denti, et colui che sona alla Lingua, et così l'altre parti di esso à quelle che sono nell'Huomo.

16. Se mai avete avuto la curiosità di vedere da vicino gli organi delle nostre chiese, sapete come i mantici spingono

l'aria in certi ricettacoli

che, mi sembra, sono

chiamati portavento, e come quest'aria entra di lì nelle canne, ora nelle une ora nelle altre, secondo le diverse maniere con cui l'organista muove le dita sulla tastiera. Ora potete qui concepire che il cuore e le arterie che spingono gli spiriti animali nelle concavità del cervello della nostra macchina, sono come i mantici di questi organi che spingono l'aria nei portavento; [dovete anche pensare] che gli oggetti esterni, secondo i nervi che muovono, fanno sì che gli spiriti contenuti in quelle cavità entrino di lì in qualcuno di quei pori, e agiscono come le dita dell'organista che, secondo i tasti che premono, fanno in maniera che l'aria entri dai portavento in alcune canne. E come l'armonia degli organi dipende

[...] soltanto da tre cose: dall'aria che viene dai mantici, dalle canne che rendono il suono, e dalla distribuzione di quell'aria sublime Organ of Creation in Kircher's Musurgia universalis (1650) simulates the divine Spirit who springs from its powerful pipes and shakes the huge mass of the World.

Descartes' Homme was far distant from the image of man that had been thought of in earlier medicine. Man was by no means a disembodied moral subject, as it happens in the ancient and modern moralists, like Lord Shaftesbury. Descartes' man was rather conceived of as a living machine endowed with sophisticated organs that were inhabited by a subtle matter akin to what we call life, responsible for those internal motions that are named, in Descartes' terms, les passions de l'âme.

The challenge of modern mechanistic medicine was exactly to explain the passions of the soul without overcoming man. Descartes the physician argues that there are in man nerves like channels inside which a subtle wind flows, extremely alive, easily shaken by the external objects. This breath or spirit is the principle of life. It was once infused in man by the divine Spirit and forms the subtle body in which man's emotional setting depends. Akin to life, the motions of the animal spirits set the mood: because of their uneasiness, they change at their leisure the temperature, the inner motions, and the general condition of the human being. Instead of the four, fixed temperaments of the traditional Hippocratic medicine, we are now opposite to a changing internal theatre whose actors are the uncontrolled motions of the spirits that circumvent the command of a disarmed reason.

Man, whom God endowed with life, was also endowed by God with the organs and functions that allow him to express and manifest his unseen, internal world. These organs and functions are those that form the sounds and words emitted by the voice, so that man could deliver his inner thoughts and desires through sounding images. L'interiorité de l'homme, whose creation Erich Auerbach once awarded to the Moderns, stays mute and silent if it lays orphan of the genius of the voice that paints the affections of the mind. In his admirable study, Le culte de la voix au XVII siècle, Salazar has shown convincingly that the voice is a construction of the modern culture: this construction has been carried on not only by rhetoricians and music theorists, but also by anatomists, physiologists, natural philosophers interested in acoustics as well as moral philosophers fully immersed in the study of the mind. 
In this way the analogy of man as a musical instrument was accomplished: man is a living musical instrument - a sensitive harpsichord Diderot will say -, capable to utter cries of sorrow, to articulate sentences, and to set in tune his deep affections by and through his voice. Moreover, man is also a resonant instrument, since he has been endowed by nature with the organs of hearing, and, what is most admirable, he is also able to convert the outer sounds and voices in inner meanings and affections. Anatomy and physiology shaped the inner map of the organs and functions responsible both of the voice and hearing, while the anatomists of the mind tried to explain the sense of hearing and the arousal of the emotions inside man. To this project the anatomists and physiologists, from Fabrizio d'Acquapendente and Casserius to Denis Dodart, offered a paramount contribution by shaping the map of all the organs that produce the voice and enable hearing. The medical side of the project was supported during seventeenth and eighteenth centuries by a further inquiry regarding the nature of the objects that liven the inner man and that the lively voice carries out into the external world. Voice, human voice, was questioned by philosophers, rhetoricians, music theorists and aestheticians, and their inquisitions accomplished the naturalistic and medical observations. Owing to their efforts, both modern medicine as well as the science of sound and anthropology achieved Kircher's speaking statue without the help of magic and sorcery, but by the aids of rational knowledge.

Let us now get through, among others, to a seventeenthcentury statement of the primary of the voice as the sounding vehicle of human affections. This is the German physician Johann Conrad Amman, in his book about deafness, Surdus loquens, siue dissertatio de loquela (1692):

Indeed, there is nothing that blows from ourselves that more vividly than our Voice can reproduce the character of life; nor without reason have I said that the voice is inhabited by the Spirit of Life, projecting through the voice its own radiations: indeed, Voice is our heart's daughter, inside which affects and desire dwell. ${ }^{16}$ (apud. SALAZAR, 1995, p. 80).

Actually, this extraordinary praise of the voice sums up the anthropology of the voice in the age of European classicism. nelle canne; così voglio avvertirvi che le funzioni di cui è qui questione, dipendono [...] soltanto dagli spiriti che vengono dal cuore, dai pori del cervello per cui passano e dalla maniera in cui questi spiriti si distribuiscono in quei pori. 
17. Nihil enim à nobis emanat, quod uiuidiorem vitæ characterem gerat quam Vox nostra, nec præter veritatem dixerim, in uoce habitare Spiritum Vitæ, per eam radios suos eiaculantes: est enim Vox proles cordis nostri, affectuum \& concupiscentiæ sedis.
The voice is, in Amman's words, the icon of the character and the heart's labour; it is also the theatre of the human desires and affections, thus giving birth to the modern aesthetics of orality and of the emotions.

About sixty years before Amman's work, in the Traité de la voix et des chants, second book of his multifarious Harmonie universelle (1636), Marin Mersenne (1588-1648) likened physionomia, the ancient craft of knowing men through the facial features, to ftongonomia, the modern craft of knowing men through the voice. In Mersenne's view, man had not one but two windows vis-à-vis du coeur: his face, whose features are the soul's mirror, and his voice, the heart's window. Just as the different features of the visage manifest the inner motions of the soul, not otherwise the acoustic qualities of the human voice are the sounding images of the interiorité de l'homme. Through the study of the voice it would be possible for Mersenne to lay down the foundation of a modern anthropology grounded upon the acoustical properties of the languages, allowing the ethnologist to classify men, genders and ways of life, and, what is paramount, also the heart's invisible motions will become visible through the voice.

However, in Mersenne's treatise, the human voice, that he called messagieure de l'interiorité, did not find the status of a modern voice, being properly able to utter only one-by-one the four characters of Hippocratic medicine:

Our voice is higher when we are sad or in anger as opposed to when we are not in this mood; the reason is that the bile makes the voice higher, while melancholy and phlegm render it lower, and the bloody temperament makes it temperate. This is the origin of high pitch being compared to fire, low to earth and water, and the tempered to the air. ${ }^{16}$ (MERSENNE, 1637 p. 8).

We must wait for Bernard Lamy's La Rhetorique, ou l'art de parler, to come across the first connection between rhetoric and the mechanical medicine based on Descartes' philosophy.

As already stated, in the Traitè de l'homme Descartes introduces the musical analogy of man and the organ in the churches. The two sounding bodies have one element in common, i.e. air, flowing through the pipes of the organ as well as through the nerves of man. In man this fluid substance takes the name and nature of the airy spirits that fill the inner space 
of the living machine, from the external senses to the brain. No longer matter not yet soul, the animal spirits enliven and paint with their motions a colourful facial physiognomy that has its instantaneous copy in the vocal image, that is, in the iconology of voice. Thanks to the Cartesian spirits, the inner place of the voice in Lamy's Art de parler gains a new anthropological dimension that was ignored by Mersenne. L'art de parler is for Lamy the capacity of correctly and elegantly painting the internal concepts and affections of the mind through sounds and words. Starting from Cicero, according to whom «all the affections of our soul have got different qualities of the voice in order to express their different nature» ("omnes affectus spiritus nostri pro sui diversitate habent proprios modos in voce, quorum nescio qua occulta familiaritate connectantur"), Lamy declares:

Since words are the signs that represent things passing through the mind, one can say that they are alike a painting of our thoughts, that the tongue is the brush that paints this picture, and that the words of the speech are its colours. ${ }^{19}$ (1998 [1675], p. 35).

Furthermore, Lamy's vocal iconology supposes the existence of an internal image in the mind that foreruns sounds and words, and inspires them:

And like the painters who do not handle their colours before making up their mind about the image that they want to imitate in the painting, before speaking we must build in our own mind an ordered image of the things that we are thinking of, and that we want to paint by way of our own words ... Our speech is the copy of the original that is in our head, and there is not a good copy of a bad original. ${ }^{20}$ (Id.ibid., p. 9).

The aim and perfection of eloquence "consists in representing with intelligence the portrait of the passions existing inside the soul» (p. 39) and to this portrait what is needed is a deep knowledge of eloquence as well as of man, since, in Lamy's words:

the passions very often engender contrary effects since they occupy the soul, making it instantly pass through very different
18. la voix est plus aiguë en la tristesse \& en la cholere, que hors de ces passions; car la bile fait la voix aiguë, la melancholie, \& le phlegme la fait grave, \& l'humeur sanguin la rend temperée. De là vient que l'aiguë est comparée au feu, la grave à la terre \& à l'eau, \& la temperée à l'air. 
19. Puisque les paroles sont des signes qui représentent les choses qui se passent dans l'esprit, on peut dire qu'elles sont comme une peinture de nos pensées, que la langue est le pinceau qui trace cette peinture, et que le mots dont le discours est composé en sont les couleurs.

20. comme les peintres ne couchent leurs couleurs qu'après qu'ils ont fait dans leur esprit l'image de ce qu'ils veulent représenter sur la toile, il faut, avant que de parler, former en nous-mêmes une image réglée des choses que nous pensons, et que nous voulons peindre par nos paroles ... Notre discours est la copie de l'original qui est en notre tête: il n'y a point de bonne copie d'un méchant original. Puisque les paroles sont des signes qui représentent les choses qui se passent dans l'esprit, on peut dire qu'elles sont comme une peinture de nos pensées, que la langue est le pinceau qui trace cette peinture, et que le mots dont le discours est composé en sont les couleurs. changes. Suddenly the passions make the soul neglect its attention towards an object compelling it to pay attention to another object that they submit to it; the passions get the soul out of control, they turn it; in one word, the passions are inside man's heart like the winds on the sea, that sometimes push the waters to the shore, sometimes cause them to enter its womb, and about at the same instant raise them to the sky, and seem to let them to go down till the centre of earth. ${ }^{21}$ (Id.ibid., p. 181-182).

In Lamy's Art de parler the inner man has got the traits of Modernity. The mise en scène of this portrait are no more the Baroque Wunderkammern, as Kircher's Roman College, but the modern Academies of the Arts and painting, and even more the changeable settings of opera, where the affections of man are set in music and tuned.

I hope that my effort to illustrate you my view of the cultural context for the affections à l'àge classique has been successful enough. One further question remains concerning the affections and their relation to voice and music: which is the modern musical form that was ordered to paint the modern soul's affections?

It is well known that in the Eighteenth-century aesthetics the airs of opera were considered the musical formulas of the affections, since people attending music theatres perceived airs as the vocal, lyric apex of the expression of the passions on the music stage. Rousseau's entry Air in the Dictionnaire still keeps intact the vivid impression that a learned and pleasant air could awaken on the Eighteenth-century listener:

A learned and pleasant Air, that has been found out by the Genius and composed by the Taste, is the music's masterpiece; there can a fine voice show itself, there a fine symphony shines; there the passion insensibly touch the soul through the senses. (...) After having listened to a fine Air, one is satisfied, the ear does not desire anything else; it remains inside the imagination, and we bring it with us, and we repeat it whenever we want; without producing one note we play it in our brain as we had listened to it during the spectacle; we see the show, the Actor, the theatre; we hear the accompaniment, the clapping. The true amateur never misses the 
fine Airs that he has listened to in his life; he lets the opera begin when he likes. ${ }^{22}$ (ROUSSEAU, 1995 [1768], p. 640).

Which is the essential quality that brings together the affections of the soul and the airs of modern opera? In other words: Is there an feature that is common to both, affections and musical imitation, therefore vindicating their theatrical linkage for about two centuries?

The answer is repetition, that is, a rhetorical and musical figure that reveals the permanent, temporal structure of the affections, that is, their repetition.

Let us read a passage of the book that dominated the cult of the passions in modern European culture, Descartes' $L e$ Passions de l'âme. His definition of the passions states:

The passions of the soul can be defined, in general, perceptions, or sentiments, or emotions of the soul, which concern the soul in particular, and are caused, maintained and reinforced by some movements of the spirits. ${ }^{23}$ (DESCARTES, 1998 [1649], p. 28).

The core of Descartes' definition of the passions of the soul is that the passions are caused, maintained and reinforced by some movements of the spirits. Unlike the sentiments or the emotions, which are the nuances of affective life, the passions capture and dominate the soul, and impose themselves for their force and continuity, and aggressive power. The modern soul's passions are not fleeting states of mind, temporary fantasies that soul lingers on. Their peculiar feature is compulsion and repetition.

Lamy seems to share completely Descartes' advice:

The passion captures the spirit of those people who are dominated by it. The passion strikingly stamps the events that gave birth to it in the soul. Therefore it is not surprising if a man, being captured by a passion, repeats again and again the same words already uttered. ${ }^{24}$ (LAMY, 1998 [1675], p. 149).

Let us finish this linkage between the affections and the musical airs with Adam Smith's essay On that imitation which takes place in the so-called Imitative arts, that was composed during the seventies of the Eighteenth-century:
21. les passions produisent aussi souvent des effets contraires car elles emportent l'âme, et la font passer en un instant par des changements bien différentes. Tout d'un coup, elles lui font quitter la considération d'un objet pour en voir un autre qu'elles lui preséntent; elles la précipitent; elles l'interrompent; elles la tournent; en un mot, les passions sont dans le cour de l'homme ce que sont les vents sur la mer, qui tantôt poussent les eaux vers le rivage, tantôt les font rentrer dans son sein, et presque dans la même instant l'élèvent jusqu'au ciel, et semblent la faire descendre jusqu'au centre de la terre.

22. Un Air savant et agréable, un Air trouvé par le Génie et composé par le Goût, est le chefd'œuvre de la Musique; c'est-là que se développe une belle voix, que brille une belle Symphonie; c'est-là que la passion vient insensiblement émouvoir l'ame par le sens. Après un bel Air, on est satisfait, l'oreille ne desire plus rien; il reste dans l'imagination, on l'emporte avec soi, on le répète à volontè; sans pouvoir en rendre une seule Note on l'exécute dans son cerveau tel qu'on l'entendit au Spectacle; on voit la Scene, l'Acteur, le Théâtre; on entend l'a c com pagnem en t, l'applaudissement. Le véritable Amateur ne perd jamais les beaux Airs qu'il entendit en sa vie; il fait recommencer l'Opera quand il veut. 
23. Les passions de l'âme sont] des perceptions, ou des sentiments, ou des émotions de l'âme, qu'on rapporte particulièrment à elle, entretenues et fortifiées par quelque mouvement des esprits.

24. La passion occupe l'esprit de ceux dont elle s'est renduë maîtresse. Elle imprime fortement les choses qui l'ont fait naître dans l'ame, ainsi il ne faut pas s'étonner qu'en étant plein, on reparle souvent des choses.
In a person who is either much depressed by grief or enlivened by joy, who is strongly affected either with love or hatred, with gratitude or resentment, with admiration or contempt, there is commonly one thought or idea which dwells upon his mind, which continually haunts him, which, when he has chased it away, immediately returns upon him, and which in company makes him absent and inattentive. He can think but of one object, and he cannot repeat to them that object so frequently as it recurs upon him. He takes refuge in solitude, where he can repeat to himself, which he does sometimes mentally, and sometimes even aloud, and almost always in the same words, the particular thought which either delights or distresses him. (...)Neither Prose nor Poetry can venture to imitate those almost endless repetitions of passion. They may describe them as I do now, but they dare not imitate them; they would become most insufferably tiresome if they did. The Music of a passionate Air not only may, but frequently does, imitate them; and it never makes its way so directly or so irresistibly to the heart as when it does so. (SMITH, 1980 [1795], p. 191-192).

It is upon this account that the words of an air, especially of a passionate one, though they are seldom very long, yet are scarce ever sung straight on to the end, like those of a recitative; but are almost always broken into parts, which are transposed and repeated again and again, according to the fancy or judgment of the composer. It is by means of such repetitions only, that Music can exert those peculiar powers of imitation which distinguish it, and in which it excels all the other Imitative Arts. "

\section{CONCLUSION}

Musica ad omnia se extendit, music encompasses everything, a Medieval writer stated. Actually, it is difficult to undervalue the contribution of musical learning to the construction of the Western image of man and his world. For more than two thousand years music contributed to achieve the image of an ordered, musical world that linked together all the mathematical sciences of the ancient quadrivium. In the modern age music was the sister science of optics, mechanics and natural philosophy, thus fostering the new concept of nature as 
matter and motion, and, conversely, opening the way to a new anthropology. Finally, within the modern system of the elegant arts, music bolstered the education of man's sensibility and moral character through the musical airs of opera that painted in music the passions of the soul throughout the European theatres.

Thus it is not pretentious to say that the image of man and his world in Western culture has been continually shaped by musical learning. Are we equal to this glorious tradition? Does current musical culture match up with this past? We do not need an answer now and here, but we should have this question with us in our daily educational work and research.

\section{BIBLIOGRAPHIC REFERENCES}

BACON, Francis. Sylva Sylvarum: or A Naturall Historie in Ten Centuries. London: William Lee, 1627

BIANCANI, Giuseppe. Echometria, id est Geometrica traditio de Echo. In: Sphaera mundi. Bononia: Cassiani, 1620

BOYLE, Robert. New experiments...touching the spring of air. In: The Works. London: Th. Birch, 1772

CUSANO, Niccolò. Dialoghi dell'idiota [1450]. In: Opere filosofiche. Torino: UTET, 1972

DESCARTES, René. Abregée de musique [Compendium musicae, 1650]. Paris: PUF, 1987

L’uomo [Traité de l'homme. Paris, 1664]. Milano: Mondadori, 1986

Le Passions de l'âme [Paris, 1649]. Paris: Flam-

marion, 1998

GALILEI, Galileo. Il Saggiatore [Roma, 1623]. Milano: Feltrinelli, 1979

GOETHE, Wolfgang. Faust [1808]. Öttingen: DTV, 1997

KEPLER, Johannes. Harmonice Munci [Linz, 1519]. In: Gesammelte Werke. München: Beck, 1940. v. 6 
KIRCHER, Athanasius. Phonurgia nova. Campidonae: Rudolphum Dreherr, 1673

LAMY, Bernard. La Rhetorique, ou l'art de parler [Paris, 1675]. Paris: Presses Universitaires de France, 1998

MERSENNE, Marin. Harmonie universelle. Paris: Pierre Ballard, 1637

MONTANARI, Geminiano. Discorso sopra Tromba parlante [1678]. Venezia: Albrizzi, 1715

ROUSSEAU, Jean Jacques. Dictionnaire de Musique [Paris, 1768]. In: Euvres complètes, V, Ecrits sur la musique et le thêatre. Paris: Éditions Gallimard, 1995

SALAZAR, Philippe. Le Culte de la Voix au XVIIe Siècle. Paris: Honoré Champion, 1995

SMITH, Adam. On that imitation which takes place in the so-called Imitative arts. [London, 1795]. In: Bryce, J.C. (ed.): The Glasgow Edition of the Works and Correspondence of Adam Smith. Oxford: Clarendon Press, 1980, v. III

ZARLINO, Gioseffo. Le istitutione harmoniche [Venetia, 1558]. Milano: R.E.A. 2011.

Sopplimenti musicali. Venetia: Francesco dei

Franceschi Senese, 1588 